Z. klin. Chem. u. klin. Biochem.

9. Jg., S. 111-116, März 1971

\title{
Difference Between the Composition of Positional Isomeric Fatty Acids from Psoriatic Scales and Normal Human Skin
}

\author{
By G. Grimmer, J. Jacob und J. Kimmig \\ University of Hamburg, Hamburg, Germany
}

(Eingegangen am 10. Oktober 1970)

\begin{abstract}
Lipids were isolated from psoriatic scales. Positional isomers of hexadecenoic, octadecenoic and octadecadienoic acids of the cholesterol csters and triglycerides were determined by oxidative cleavage $\left(\mathrm{MnO}_{4} / 1 \mathrm{O}_{4}\right)$. The following hexadecenoic acids werc present: 4-hexadecenoic acid $(1.5 \%), 6-(10.6 \%), 7-(2.7 \%), 8-(1.1 \%), 9-(83.3 \%), 10-(0.8 \%), 11-$ (trace). Among the octadeccnoic acids $8-$ octadecenoic acid $(4.2 \%), 9-(81.3 \%), 10-(3.7 \%)$ and $11-(10.9 \%)$ could be observed, whereas 8.11 -octadecadienoic acid $(5.1 \%), 9.12-(91 \%)$, $10,13-(0.1 \%)$ and $11.14-(3.8 \%)$ were detected.

The fat, separated from the psoriatic scales, contains only very little 6-hexadecenoic acid which is specific for skin fat, but it is very similar to human depot fat.
\end{abstract}

Nach Isolierung der Lipide aus Psoriasisschuppen wurde dic Zusammensetzung der isomeren Hexadecen-, Octadecen- und Octadecadiensäuren der Cholesterinester und der Triglyceride durch oxydative Spaltung mit $\mathrm{MnO}_{4} / \mathrm{IO}_{4}$ bestimmt. Dic Feinstruktur der Hexadecensäuren zeigte das Vorkommen von $4-(1.5 \%), 6-(10.6 \%), 7-(2.7 \%), 8-(1.1 \%), 9-(83.3 \%), 10-(0.8 \%)$ und $11-$ Hexadecensäure (Spur). Die Octadecensäuren erwiesen sich als Isomerengemisch aus 8- (4.2\%), 9- $(81.3 \%), 10-(3.7 \%)$ und $11-$ Octadecensäure $(10.9 \%)$, während bei den Octadecadiensäuren $8.11-(5.1 \%), 9.12-(91 \%), 10.13-(0.1 \%)$ und 11.14-Octadecadiensäure $(3.8 \%)$ nachgewiesen wurden.

Das aus Psoriasisschuppen isolierte Fett zeigt eine auffällige Ahnlichkeit mit menschlichem Depotfett und enthält nur wenig 6Hexadecensäure, die spezifischer Bestandteil menschlichen Hautfettes ist.

Psoriasis (psoriasis vulgaris) is characterized by an increased production of epidermal skin tissue which leads to a strong production of scales. Though the cause of this disease is still unknown some details of it (certain inheritance, therapeutic effects of high energy radiation and diet) lead to the conclusion that one should look for a metabolic effect resulting from a genetic defect. (1).

Nevertheless an infection is still not excluded as a possible cause. In the case of a genetic defect in the synthesis or regulation of enzymes, at least a quantitative difference between the metabolism of normal and psoriatic skin should be observed.

This paper deals only with the lipid metabolites, and the possibility remains that the defect could also be revealed by changes in the protein, nucleic acid or carbohydrate metabolism.

A pathological change of the lipid metabolism has been repeatedly reported, manifested as increased values of free cholesterol or triglycerides $(2,3,4)$ or of other lipids in serum $(5,6)$ as well as a change of the skin lipids (7-10). These results were contradicted $(11,12$, 13) or refuted (14) by various authors.

Many investigations deal with the enzyme activity of psoriatic skin (15-24).

We have now investigated the unpolar lipids of psoriatic scales separating them into hydrocarbons, cholesterol esters, waxes, triglycerides, alcohols, cholesterol and free fatty acids.

After re-esterfication of the fatty acid-containing lipids with methanolic $\mathrm{HCl}$, the quantitative composition of the fatty acids was determined by gas liquid chromatography. The fatty acid methyl esters were converted into their mercuric acetate adducts by $\mathrm{Hg}$-[II]-acetate. They can then be separated into saturated, monoenoic and dienoic methyl esters.

The separation of the hexadecenoic, octadecenoic and octadecadienoic methyl esters was performed by preparative gas liquid chromatography (25). Finally the cleavage by periodate-permanganate oxidation yielded the quantitative composition of the positional isomers $(26,27)$.

The lipid composition of the healthy skin has been the subject of repeated investigation (28-32). The review of HAAHTI (30) deals with the composition of the single lipid groups and their fatty acids, whereas NrcoLAIDES (33) reported the composition of the isomer dienoic fatty acids from normal skin.

The isomeric monoenoic fatty acids from hair fat were investigated by WEITKAMP (28) and their composition in skin fat by Nicolardes (29). They showed the 6-isomers, which are normally only minor components of naturally occurring fats, to be the main components.

\section{Material and Methods}

Material

The investigations were carried out on four different samples of scales (I-IV). I and II are scales collected from several patients, whereas III and IV result form two separate female patients.

Method

The method of separation ist given schematically in figure 1 . 


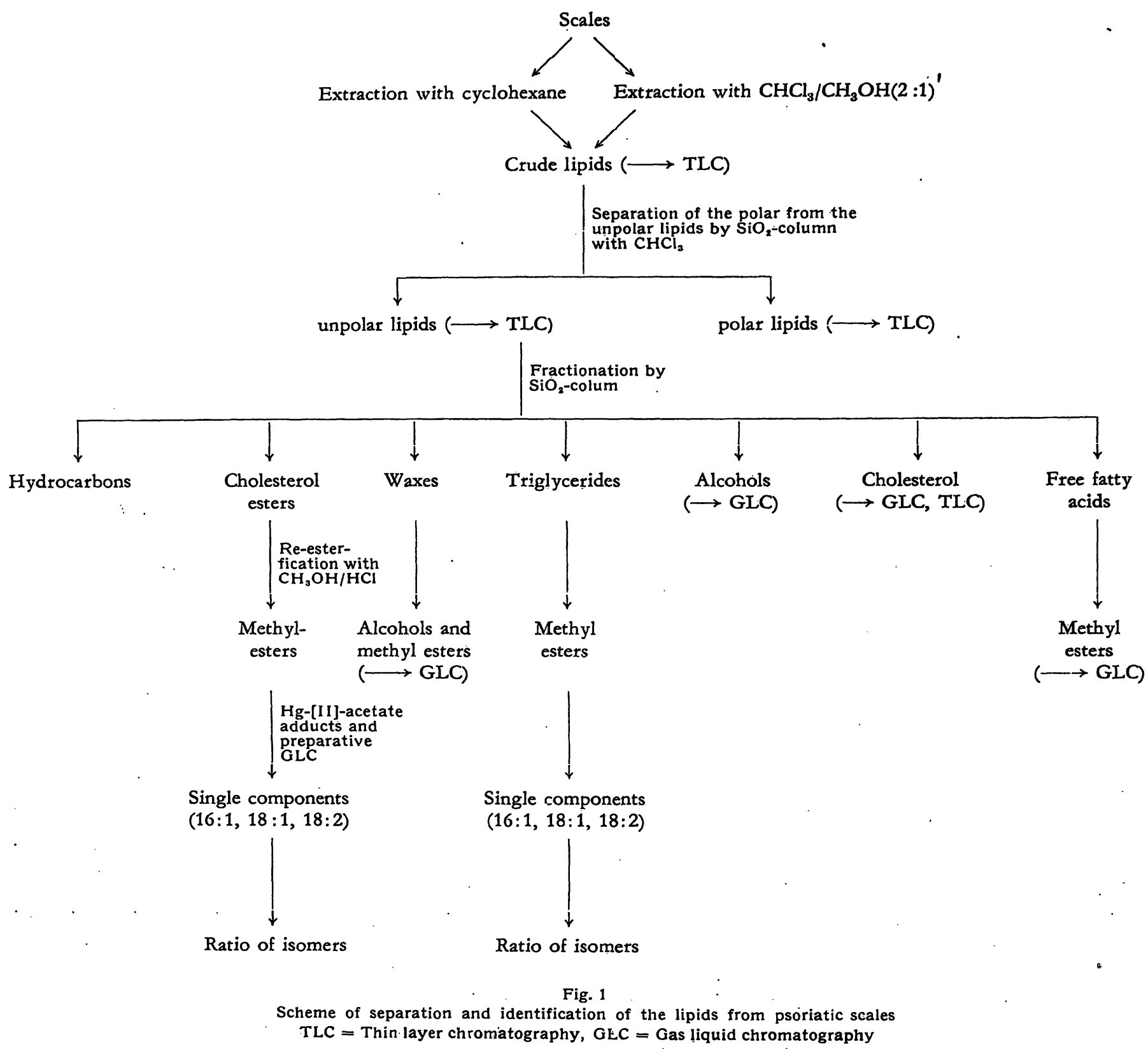

\section{Extraction of the scales}

The scales were extracted with a 20 -fold weight of cold cyclohexane; the solution was evaporated at $30^{\circ}$ and $14 \mathrm{~mm} \mathrm{Hg}$ and the residue weighed.

The scales then were extracted with a 20 -fold quantity of a mixture of $\mathrm{CHCl}_{3} / \mathrm{CH}_{3} \mathrm{OH}(2: 1 \mathrm{v} / \mathrm{v})$ for $60 \mathrm{~min}$. The solution was filtered and diluted with water to give two equal layers. The $\mathrm{CHCl}_{3}$-phase was evaporated and weighed.

\section{Separation of the polar from the unpolar lipids}

The separation was performed on silica gel (20 times the amount of $\mathrm{SiO}_{2}$, uniform grain size $(0.16 \mathrm{~mm})$, washed with $\mathrm{CHCl}_{3}$, otherwise untreated). The unpolar lipids were eluted by the 12 -fold amount of $\mathrm{CHCl}_{3}$ (in relation to silica gel), the polar by the same amount of methanol and $5 \%$ water.

\section{Fractionation of the unpolar lipids}

The fractionation was performed on the silica gel column described above with an elution gradient of $\mathrm{CCl}_{4} / \mathrm{CHCl}_{3} .25 \mathrm{~g} \mathrm{SiO}_{2}$ were treated with $75 \mathrm{~m} / \mathrm{CCl}_{4}, \mathrm{CCl}_{4}$ with $5,10,20,40,60$ and $80 \%$ $\mathrm{CHCl}_{3}$, respectively, and finally with pure $\mathrm{CHCl}_{3}$. The fractions, collected as $25 \mathrm{~m}$-samples, were investigated by thin layer chromatography and weighed after evaporation of the solvent.

\section{Thin layer chromatography}

Air dried $\mathrm{SiO}_{2}$-gel-PF plates (E. Merck) were used which were developed with $\mathrm{CHCl}_{3} / \mathrm{CCl}_{4}(1: 1 \nabla / v)$ by the ascending technique. Hydrocarbons could also be separated on commercial $\mathrm{Al}_{2} \mathrm{O}_{3}-\mathrm{E}$ plates (E. Merck) with iso-octane/cyclohexane $(1: 1 \mathrm{v} / \mathrm{v})$. Alcohols, triglycerides, waxes and cholesterol were separated on silica gel (PF) plates by $\mathrm{CHCl}_{3}$. The spots were detected with chromsulphuric acid by heating for $5 \mathrm{~min}$. at $130^{\circ}$.

Separation of the metbyl esters into saturated, monoenoic and dienoic esters

The separation of the methyl esters according to their degree of saturation was performed by the mercuric acetate method $(34,35)$. The methyl esters of the cholesterol esters and triglycerides were dissolved in $5 \mathrm{ml}$ of $10 \%$ methanolic $\mathrm{Hg}-[\mathrm{II}]$-acetate, respectively, and allowed to stand for 48 hours. After evaporation of the solvent at $25^{\circ}$ and $14 \mathrm{~mm} \mathrm{Hg}$ the residue was extracted twice with portions of $100 \mathrm{~m} /$ benzene. The solvent-free mixture of saturated methyl esters and $\mathrm{Hg}$-adducts were developed on silica gel plates $\mathrm{SiO}_{2}$ Merck for preparative thin layer chromatography) first with petrol ether/diethyl ether $(8: 2 \mathrm{v} / \mathrm{v})$ and then with n-propanol/acetic acid $(100: 1 \mathrm{v} / \mathrm{v})$ shortly behind the first solvent front. The substances were detected by hydrogen sulphide. After scraping the single. 


\title{
Kompensations-Polarimeter OK $1^{1}$
}

\author{
rationell \\ genau \\ automatisch
}

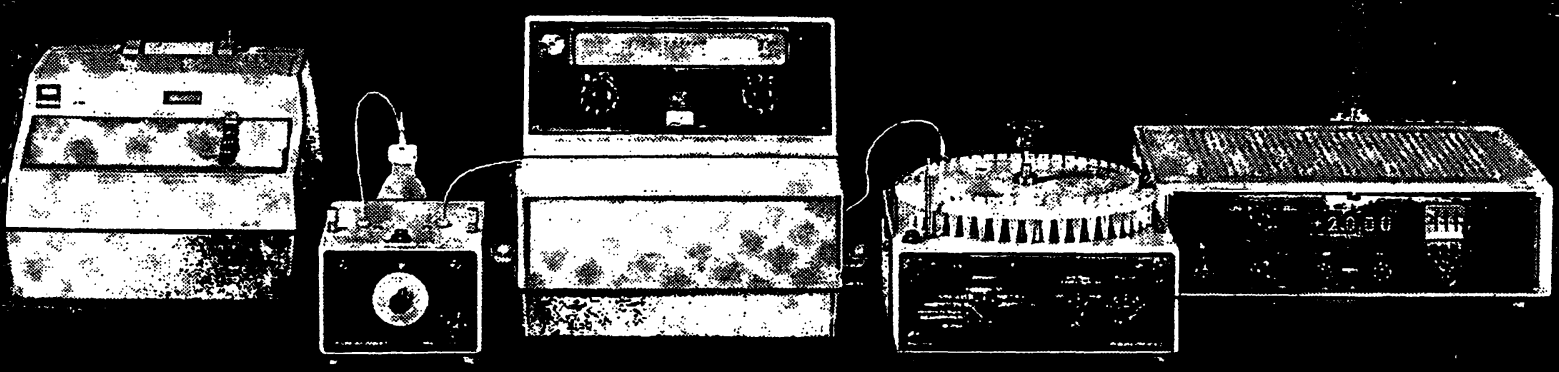

120 Harnzuckerbestimmungen pro Stunde.

Direkte Konzentrationsanzeige.

Einfachste Bedienung.

Automatische Probenzufuhr.

Digitale Anzeige und Dokumentation.

Extrem große Empfindlichkeit.

Große Extinktionsreserve pro cm Schicht. Anpassungsfähig für große und kleine Labors.

\section{ThINE}

CARL ZEISS 7082 Oberkochen/Württ. 

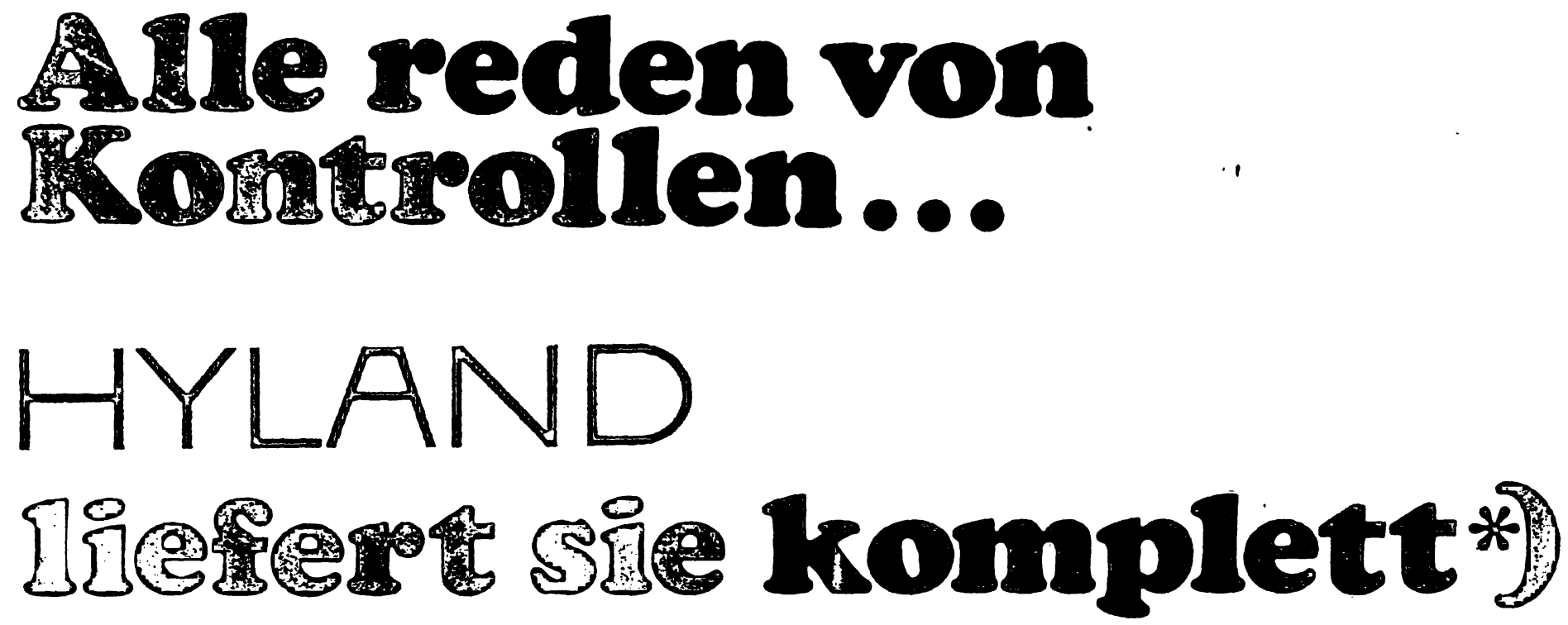

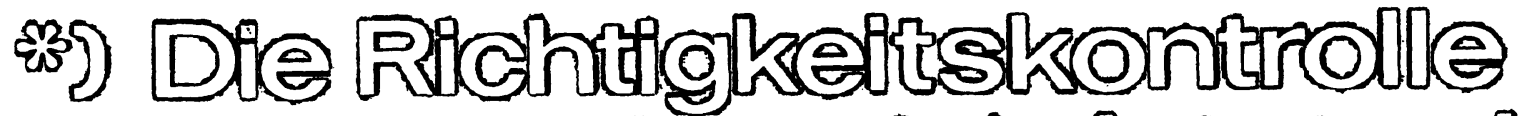

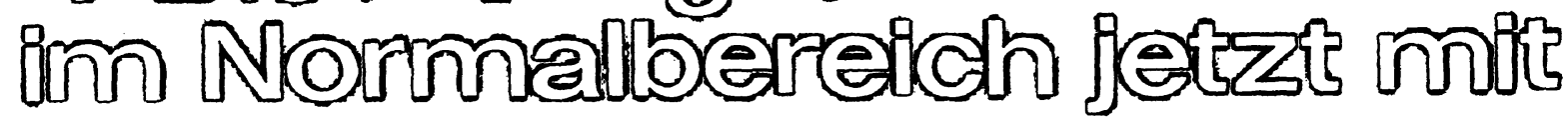

EUROPAW

Protarsisionskontrollen

Humanseren, Normal - Pathologisch

Humanserum „Q Pak” für Analyseautomaten

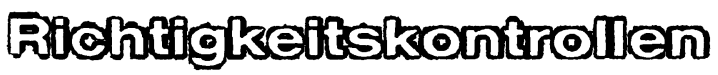

Humanseren, Normal - Pathologisch - Spezial

Humanserum "O Pak" für Analyseautomaten

Multi-Enzym-Referenzserum

Bilirubinkontrolle mit erhöhten Werten

Cholesterinkontrolle mit erhöhten Werten

Kontrollurine

Kontroll-Liquor

HB-Referenzstandard und -Kontrolle

-

Informieren Sie sich bitte. Verlangen Sie unsere Literatur- und Informationsunterlagen.

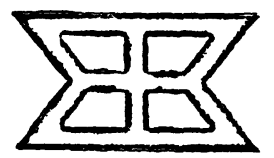

TRAVENOL INTERNATIONAL GMBBH

8 München 2, Postfach 202429, Tel. (0811) 539376 
fractions from the plate, the mercuric adducts were decomposed by treatment with $5 \%$ methanolic $\mathrm{KSCN}$-solution and concentrated $\mathrm{HCl}$ for $60 \mathrm{~min}$. The free methyl esters were extracted with cyclohexane after diluting the mixture with an equal amount of water.

\section{Re-esterfication}

The re-esterfication of the fatty acid-containing lipids was performd with $5 \%$ methanolic $\mathrm{HCl}$ at $80^{\circ}$ for $45 \mathrm{~min}$. The methyl esters were extracted with cyclohexane after diluting the mixture with an equal volume of water. The methyl esters and alcohols resulting from the re-esterfication of the waxes were extracted with $\mathrm{CHCl}_{3}$ and separated by silica gel column chromatography with $\mathrm{CCl}_{4}$ (methyl esters) and $\mathrm{CHCl}_{3}$ (alcohols), respectively (36).

\section{Gas liquid chromatography}

All gas liquid chromatography investigations were carried out with a fractograph F 7/4 H from Perkin-Elmer \& Co. Bodenseewerk Uberlingen, Germany, with a flame ionization detector and an electronic integrator D 2, 159-008.

For the separation of the methyl esters and alcohols the following types of columns were used:

a) Capillary column, $25 \mathrm{~m}$ long, inner diameter $0.25 \mathrm{~mm}$, P-E-type 2G51, stationary phase: butanediol-succinate polyester; temperature $170^{\circ}$; flow rate $1 \mathrm{~m} / \mathrm{N}_{2} / \mathrm{min}$.

b) Packed column (steel), $2 \mathrm{~m}$ long, inner diameter $4.65 \mathrm{~mm}$, stationary phase: diethylenglycol-succinate $20 \%$ on celite at various temperatures; flow rate $35 \mathrm{~m} / \mathrm{N}_{2} / \mathrm{min}$.

c) Packed column (steel), $2 \mathrm{~m}$ long, inner diameter $4.65 \mathrm{~mm}$, stationary phase: apiezon $M 10 \%$ on Chromosorb $R$ at various temperatures; flow rate $55 \mathrm{~m} / \mathrm{N}_{2} / \mathrm{min}$.

Squalene and other hydrocarbons were investigated by a column type:

d) Packed column (steel), $2 \mathrm{~m}$ long, inner diameter $3 \mathrm{~mm}$, stationary phase: JXR (SE 30) $3 \%$ on GasChrom $Q$ with temperature program from $100-300^{\circ}\left(5^{\circ} / \mathrm{min}\right.$.); flow rate $30 \mathrm{ml} \mathrm{N} / 2 / \mathrm{min}$. The identification of the compounds was performed by adding authentic material.

\section{Preparative gas liquid chromatograplyy}

We reported the preparative gas liquid chromatography in a previous paper (25). The above mentioned column b. was used for this. The preparation gas liquid chromatography delivered mixtures of positional isomers of hexadecenoic, octadecenoic and octadecadienoic methyl esters which were more than $99.9 \%$ pure (Fig. $2 \mathrm{a}-\mathrm{c})$.

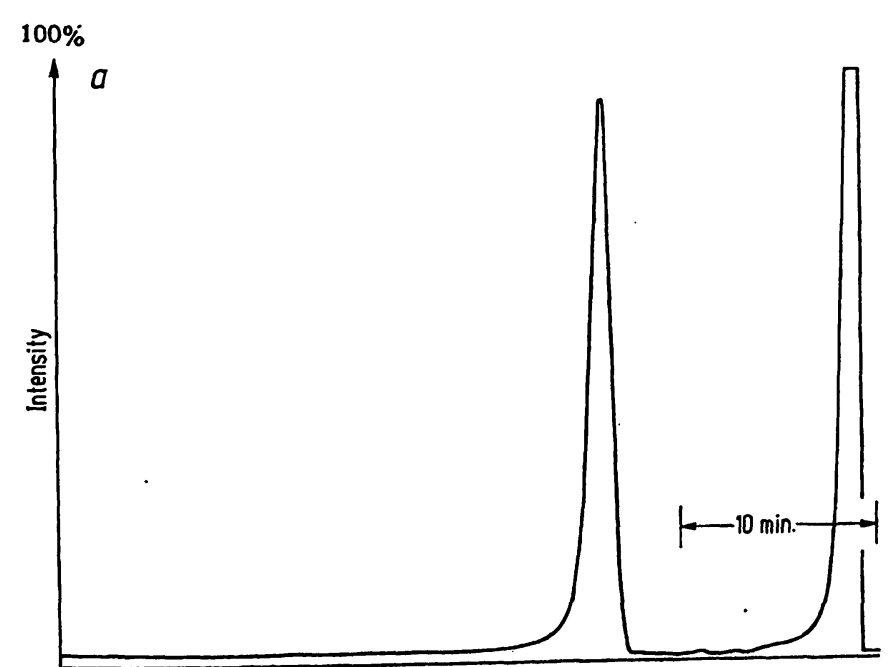

$\leftarrow$ Retention time

Fig. 2 a Hexadecenoic acid isolated from triglycerides before oxidative cleavage, Purity of the fraction after separation by the Hg-addu

Z. klin. Chem. u. klin. Biochem. / 9. Jahrg. 1971/ Heft 2

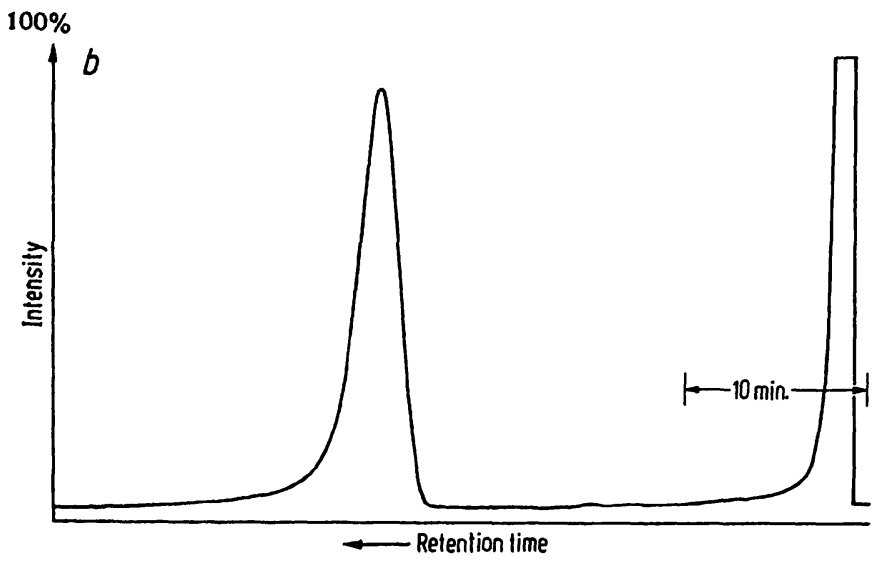

Fig. $2 b$

Octadecenoic acid isolated from triglycerides before oxidative cleavage (purification see fig. 2 a)

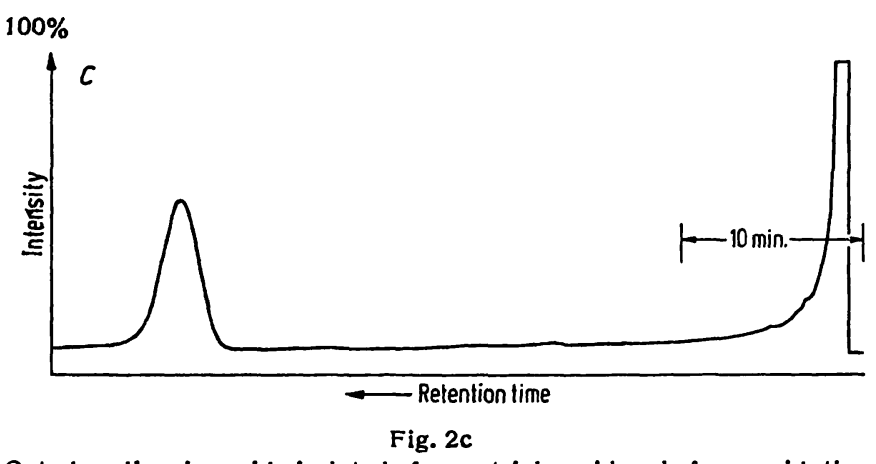
Octadecadienoic acid isolated from triglycerides before oxidative
clcavage (puricifation see fig. 2a)

\section{Oxidative cleavage with $\mathrm{MnO}_{4} / \mathrm{IO}_{4}$}

The oxidative cleavage of monoenoic and dienoic methyl esters has already been reported extensively $(26,27)$.

\section{Results}

The results of the fractionation into the single lipid groups are given in table 1.

Tab. 1

Composition of the lipids from psoriatic scales

\begin{tabular}{|c|c|c|c|c|}
\hline Fraction & $\begin{array}{c}\text { Weights of } \\
\text { I }\end{array}$ & II & $\begin{array}{l}\text { om patients } \\
\text { III }\end{array}$ & S I-IV \\
\hline \multirow{8}{*}{$\begin{array}{l}\text { Scales (g) } \\
\text { Extraction with } \\
\text { cyclohexane (g) } \\
\text { Extraction with } \\
\text { CHCl /CH,OH (g) } \\
\text { Crude lipids, total (g) } \\
\text { Crude lipids, total (\%) } \\
\text { Polar lipids (mg) } \\
\text { Protein (mg) } \\
\text { Unpolar lipids (mg) } \\
\text { Hydrocarbons (mg) } \\
\text { Other unpolar lipids (mg) } \\
\text { Cholesterol esters (mg) } \\
\text { Waxes (mg) } \\
\text { Triglycerides (mg) } \\
\text { Alcohols (mg) } \\
\text { Cholesterol (mg) } \\
\text { Free fatty acids (mg) }\end{array}$} & 15.7 & 6.861 & 0.1924 & 0.0539 \\
\hline & 1.0176 & 0.5076 & 0.1160 & 0.0111 \\
\hline & $\begin{array}{c}0.4977 \\
1.5153 \\
9.7 \\
204.4 \\
80.8 \\
1230.0 \\
771.2 \\
433.6\end{array}$ & $\begin{array}{l}0.3431 \\
0.8507 \\
12.4 \\
101.0 \\
128.0 \\
621.0 \\
310.0\end{array}$ & $\begin{array}{c}0.0065 \\
0.0181 \\
9.4 \\
3.3 \\
3.9 \\
10.9 \\
5.7 \\
4.9\end{array}$ & $\begin{array}{c}0.0023 \\
0.0054 \\
10.0 \\
2.3 \\
0.4 \\
2.9 \\
1.9 \\
1.0\end{array}$ \\
\hline & & 二 & - & - \\
\hline & 27.0 & - & - & - \\
\hline & & - & - & - \\
\hline & & - & 二 & 二 \\
\hline & & - & - & - \\
\hline
\end{tabular}

In the following the quantitative compositions of the lipid groups are reported.

\section{Hydrocarbons}

Thin layer and gas liquid chromatography give identical results for the composition of this group in the patients I-IV. Among little amounts of squalene there 


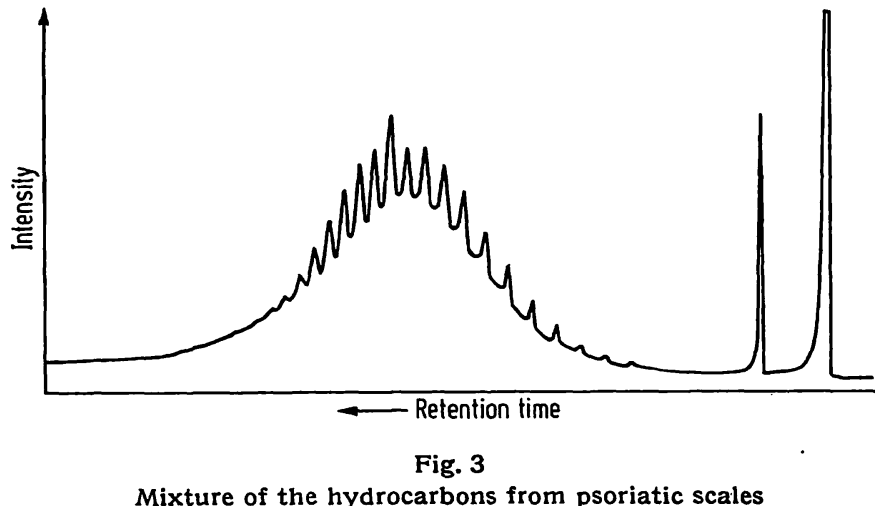

is found a mixture of paraffins with a chain length of $\mathrm{C}_{23}-\mathrm{C}_{36}$ (Fig. 3). There is still another unidentified substance with a shorter retention time. Simultaneously investigated ointment bases (adeps lanae, white vaselin, eucerine, unguentum etc.) however leads to the conclusion that the mixture of hydrocarbons originates from white vaselin, though all investigated patients had remained untreated for a long time.

\section{Cholesterol esters}

The fatty acid composition of the cholesterol esters is shown in table 2.

Tab. 2

Fatty acids from the cholesterol esters (in mole-\%)

\begin{tabular}{cc} 
fatty acid & mole- $\%$ \\
(Carbon atoms: double bonds) & \\
\hline $12: 0$ & 2.2 \\
$13: 0$ & 0.1 \\
$14: 0$ & 6.6 \\
$14: 1$ & 1.0 \\
$15: 0$ & 3.5 \\
$16: 0$ & 22.7 \\
$16: 1$ & 10.0 \\
$17: 0$ & 0.8 \\
$17: 1$ & 1.2 \\
$18: 0$ & 10.0 \\
$18: 1$ & 34.2 \\
$18: 2$ & 6.0 \\
$18: 3$ & 1.6 \\
$19: 0$ & trace
\end{tabular}

\section{Waxes}

After re-esterfication of the waxes with methanolic $\mathrm{HCl}$ and separation of the methyl esters from the alcohols by silica gel column chromatography the following fragments are found. (Tab. 3).

Tab. 3

\begin{tabular}{|c|c|c|c|}
\hline \multicolumn{2}{|c|}{$\begin{array}{l}\text { a) Composition of the } \\
\text { fatty acids from the } \\
\text { waxes in mole- } \% \\
\text { fatty acid mole- } \% \\
\text { (Carbon atoms: }\end{array}$} & \multicolumn{2}{|c|}{$\begin{array}{l}\text { b) Composition of the } \\
\text { wax alcohols in } \\
\text { mole- } \%\end{array}$} \\
\hline $\begin{array}{l}14: 0 \\
15: 0 \\
16: 0 \\
16: 1 \\
17: 0 \\
17: 1 \\
18: 0 \\
18: 1 \\
18: 2 \\
18: 3 \\
19: 0 \\
20: 0\end{array}$ & $\begin{array}{c}2.4 \\
1.4 \\
22.2 \\
7.0 \\
\text { trace } \\
1.1 \\
11.6 \\
41.7 \\
12.6 \\
\text { trace } \\
\text { trace } \\
\text { trace }\end{array}$ & $\begin{array}{l}10: 0 \\
12: 0 \\
13: 0 \\
14: 0 \\
15: 0 \\
16: 0 \\
16: 1 \\
17: 0 \\
18: 0 \\
18: 1\end{array}$ & $\begin{array}{r}3.6 \\
0.7 \\
0.9 \\
4.5 \\
3.6 \\
41.4 \\
0.3 \\
4.0 \\
38.3 \\
2.7\end{array}$ \\
\hline
\end{tabular}

\section{Triglycerides}

Table 4 shows the composition of the fatty acids from the triglycerides after re-esterfication with methanolic $\mathrm{HCl}$.

Tab. 4

Composition of the fatty acids from the triglycerides in mole-\%

\begin{tabular}{cc} 
fatty acid & mole- $\%$ \\
(Carbon atoms: double bonds) & \\
\hline $12: 0$ & 0.2 \\
$14: 0$ & 2.9 \\
$15: 0$ & 3.1 \\
$16: 0$ & 17.6 \\
$16: 1$ & 10.8 \\
$17: 0$ & 1.3 \\
$17: 1$ & 1.1 \\
$18: 0$ & 9.2 \\
$18: 1$ & 37.9 \\
$18: 2$ & 15.8 \\
$18: 3$ & trace \\
$19: 0$ & trace \\
\hline
\end{tabular}

\section{Alcohols}

The composition of the free alcohols is shown in table 5. Figure 4 shows the gas liquid chromatography of the free alcohols.

Tab. 5

Composition of the free alcohols

\begin{tabular}{cc} 
alcohol & mole- $\%$ \\
(Carbon atoms: double bonds) & \\
\hline $10: 0$ & trace \\
$12: 0$ & 0.9 \\
$14: 0$ & 1.6 \\
$16: 0$ & 45.0 \\
$17: 0$ & trace \\
$18: 0$ & 52.5 \\
\hline
\end{tabular}

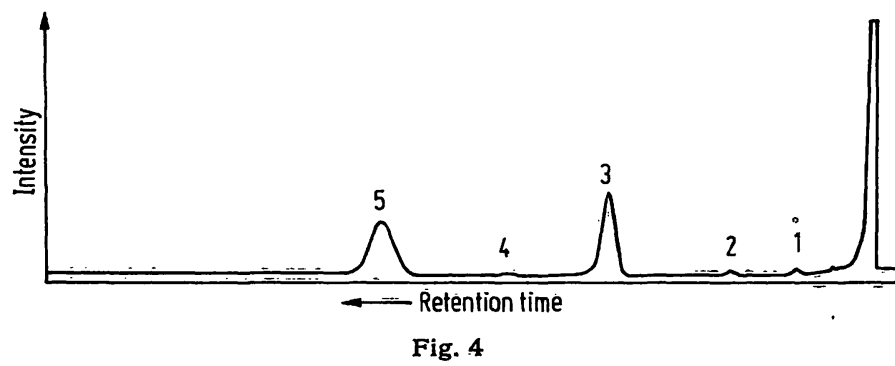

Gas liquid chromatography of the free higher alcohols from psoriatic scales $1=$ dodecanol-1, $2=$ tetradecanol-1, $3=$ hexadecanol- 1 ,

\section{Free fatty acids}

Table 6 shows the composition of the free fatty acids. The investigation of the fatty acids from the cholesterol esters and the triglycerides which are together with

Tab. 6

Composition of the free fatty acids in mole- $\%$

\begin{tabular}{cc} 
fatty acid & mole- $\%$ \\
\hline (Carbon atoms: double bonds) & 5.2 \\
$12: 0$ & 4.1 \\
$14: 0$ & trace \\
$14: 1$ & 2.6 \\
$15: 0$ & trace \\
$15: 1$ & 25.7 \\
$16: 0$ & 9.2 \\
$16: 1$ & 2.5 \\
$17: 0$ & 1.6 \\
$17: 1$ & 17.1 \\
$18: 0$ & 32.1 \\
$18: 1$ & trace \\
$18: 2$ & trace \\
$19: 0$ & trace \\
$20: 0$ & trace. \\
$21: 0$ &
\end{tabular}


cholesterol the main components of the unpolar lipids, leads to the isomeric composition of hexadecenoic, octadecenoic and octadecadienoic acid as shown in table 7, after separation of the mixture of all methyl esters by mercuric acetate adducts, preparative gas liquid chromatography and oxidative cleavage.

Tab. 7

Ratio of isomers of hexadecenoic, octadecenoic and octadecadienoic acids from psoriatic scales, determined by oxidative cleavage

The values in brackets show the percentages (in mole-\%) of the total fatty acid composition

\begin{tabular}{cccccc}
\hline $\begin{array}{c}\text { fatty } \\
\text { acid }\end{array}$ & $\begin{array}{c}\text { position } \\
\text { of the } \\
\text { double bond }\end{array}$ & \multicolumn{2}{c}{$\begin{array}{c}\text { cholesterol esters } \\
\text { percentage of the positional isomers }\end{array}$} \\
\hline $16: 1$ & 4 & 1.5 & $(0.1)$ & 0.7 & $(0.1)$ \\
& 6 & 10.6 & $(1.1)$ & 4.5 & $(0.5)$ \\
& 7 & 2.6 & $(0.3)$ & 3.6 & $(0.4)$ \\
& 8 & 1.1 & $(0.1)$ & 1.1 & $(0.1)$ \\
& 9 & 83.3 & $(8.3)$ & 89.4 & $(9.8)$ \\
& 10 & 0.8 & $($ trace) & 0.7 & $(0.1)$ \\
$18: 1$ & 11 & trace & $($ trace) & trace & $($ trace) \\
& 8 & 4.1 & $(1.4)$ & 2.9 & $(1.1)$ \\
& 9 & 81.3 & $(27.8)$ & 86.8 & $(32.9)$ \\
& 10 & 3.7 & $(1.3)$ & 2.7 & $(1.0)$ \\
$18: 2$ & 11 & 10.9 & $(3.7)$ & 7.3 & $(2.9)$ \\
& 8.11 & 5.1 & $(0.3)$ & 3.4 & $(0.5)$ \\
& 9.12 & 91.0 & $(5.5)$ & 92.0 & $(14.6)$ \\
& 10.13 & 0.1 & $($ trace) & 0.1 & $($ trace) \\
& 11.14 & 3.8 & $(0.2)$ & 4.5 & $(0.7)$ \\
\hline
\end{tabular}

\section{Discussion}

Though little amounts of n-alkanes $(1-7.5 \%$ of the total lipids) have been determined in healthy skin $(30,37)$ we tend to the opinion that the high amounts of hydrocarbons (54\%) reported in this paper are artefacts which originate from white vaselin. Though the investigated patients were untreated for a long time we could find in all patients about the same quantities of hydrocarbons; this shows that hydrocarbons remain for more than weeks in the skin, and that it is difficult to eliminate them.

The values of the triglycerides and cholesterol esters are comparably low but the value of the free cholesterol is remarkably high as reported already by other authors (7-9). In addition to hexadecanol, first reported by KImMrg (33), we could show that octadecanol occurs in about the same quantity. These alcohols do not occur in the free form in healthy skin according to HaATHI (30).

The high level of free fatty acids in healthy skin reported by Weitkamp (28), HaAthi (30) and Rothman (38) (about $20-30 \%$ ) could not be established in psoriatic scales.

The analysis of the fine structure of the fatty acids $(16: 1,18: 1,18: 2)$ from the triglycerides and cholesterol esters in psoriatic scales shows predominating 9-isomers. The predominating 6-position in hexadecenoic, 8-position in octadecenoic and 5.8position in octadecadienoic acid as reported by WEITKAMP (28) and Nicolaides $(29,33)$ could not be established in psoriatic scales. Though the above mentioned authors investigated only the free fatty acids it should be valid to apply their results to the other lipid groups, since NicolaIdes (29) has drawn attention to the biogenesis of the free fatty acids from the triglycerides.

The figures 5-7 compare the results drawn from healthy $(29,33)$ skin fat and psoriatic scales with the

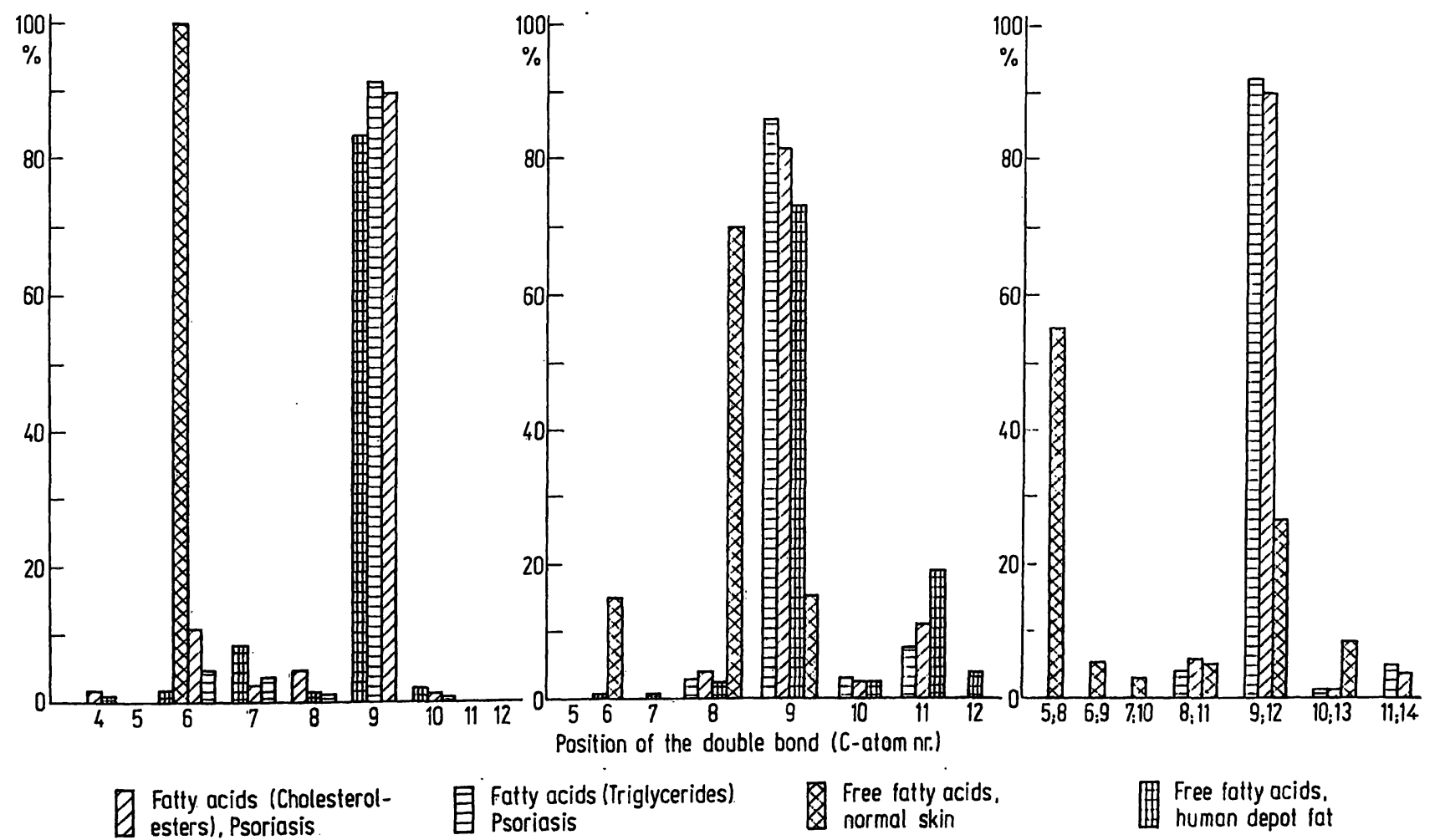

Fig. 5

Comparison of the isomeric hexadecenoic acids from psoriatic scales, healthy skin and human depot fat
Fig. 6

Comparison of the isomeric octadecenoic Comparison of the isomeric octadecenoic acids from psoriatic cales, heal
human depot fat
Fig. 7

Comparison of the isomeric octadecadienoic acids from psoriatic scales and healthy skin 
composition of the fatty acids from human depot fat (35).

The figures show an obvious similarity between the fine structure of the investigated fatty acids isolated from psoriatic scales and from human depot fat. The pattern of isomers of healthy skin seems to be suppressed in psoriasis. The possibly essential enzyme system which performs the dehydrogenation of the fatty acids in 6-position and so produces 6-hexadecenoic acid and by chain elongation 8-octadecerioic acid and perhaps 5.8octadecadienoic acid seems to be partially damaged, so that an approximation of the skin fat to the depot fat can be observed. As to our results, however, the enzyme which performs chain elongation is still intact, which can be concluded from the relatively high content of 11-octadecenoic acid.

This work was supported by the Deutsche Forschungsgemeinschaft, Bad Godesberg, Deutschland.

\section{References}

1. SChÖNFELD, W. and W. SCHNEIDER, Lehrbuch der Haut- und Geschlechtskrankheiten, 10. Aufl. G. Thieme Verlag, Stuttgart (1969). - 2. YableniK, B. S., Vestn. venerol. dermat., Moskva 2, 29 (1946). - 3. RÁdL, J., Z. Kraus and M. Toušek, Dermat. W/schr. Leipzig 135, 609 (1957). - 4. Piccinelli, O., F. Nicrosini and S. MAINOLI, Arch. stud. fisiopat. ricambio, 21, 592 (1957). - 5. Fedorskaya, R. F., N. A. Dobrotina and K. P. VenedikTova, Zh. khim. biol. khim. Abstr. Nr. 22 S 1200 (1962). 6. KaNsky, A., Zschr. Haut- u. Geschl.krkh. Berlin 30, 153 (1961). - 7. Carrié, C. and H. Neuhaus, Arch. Dermat. Syph., 188, 314 (1949). - 8. Gross, P. and B. M. Kesten, N. Y. State J. Med., 50, 2683 (1950). - 9. Manganottr, G., A. Muccinelli, A. Longhr and C. Rossonr, Lipidi Aliment. Attività Epatiche, Atti Conv. 20, Rimini, Italy (1961). - 10. Kimmig, J., Arch. Klin. Exper. Dermat. 227, 826 (1966). - 11. Tello, E. E. and B. A. Mracola, Rev. Asoc. bioquim. argent. 22, 278 (1957). 12. LEA, W. A., H. H. Cornish and W. D. BlOCK, J. Invest. Dermatol. 30, 181 (1958). - 13. Pezzarossa, G., Ateneo parmense, 31, 541 (1960). - 14. WrLkinson, D. I. and E. M. FARber, J. Invest. Dermatol. 49, 526 (1967). - 15. BraunFalco, O., Arch. Klin. Exqer. Dermat. 216, 130 (1963). - 16. Jones, W. A., E. B. Helivig and L. E. Harmon, J. Invest. Dermatol. 44, 189 (1965). - 17. KANSKY, A., Arch. Klin. Exper. Dermat. 223, 393 (1965). - 18. Rassner, G., Arch. Klin. Exper. Dermat. 225, 398 (1966). - 19. WILKInson, D. I., J. Invest.
Dermatol. 47, 185 (1966). - 20. Rassner; G., Arch. Klin. Exper. Dermat. 226, 111 (1966). - 21. BojanovskA, A., Bratislavské lek. listy, 47, 399 (1967). - 22. BojAnovska, A., Bratislavské lek. listy, 47, 393 (1967). - 23. HAMmER, H., N. Thyresson and S. E. Brolin, Acta dermat.-venereol. 48, 175 (1968). - 24. De Bersaques, J., Arch. Klin. Exper. Dermat. 234, 52 (1969). 25. JACOB, J. and G. GRIMMER, Z. Naturforsch. 25b, 54 (1970). 26. GrImMER, G. and J. JACOB, Z. Naturforsch. 24b, 565 (1969). 27. Grimmer, G. and J. JACOB, Z. Naturforsch. 24b, 1004 (1969). - 28. Weitkamp, A. W., A. M. Smiljanic and S. Rothman, J. Amer. Chem. Soc. 69, 1936 (1947). - 29. Nicolardés, N., R. E. Kellum and P. V. Woolley III, Arch. Biochem. Biophysics 105, 634 (1964). - 30. HaAthr, E. in 'Major lipid constituents of human skin surface', Mercatorin Kirjapaino, Helsinki (1961). 31. HaAthi, E., E. C. Horning and O. Castren, J. Clin. Laborat. Invest. 14, 368 (1962). - 32. WheAtley, V. R., and P. Flesh, J. Invest. Dermatol. 49, 198 (1967). - 33. Nrcolaides, N. and M. N. A. Ansari, Lipids, 4, 79 (1969). - 34. JANTZEN, E. and H. Andreas, Chem. Ber. 94, 628 (1961). - 35. JACOB, J. and G. Grimmer, J. Lip. Res. 8, 308 (1967). - 36. JACOB, J. and A. ZEMAN, Z. Naturforsch. in press. - 37. WHEATLEY, V. R., Biochem. Soc. Symposia, 9, 14 (1952). - 38. Rothman, S. in 'Physiology and biochemistry of the skin', University of Chicago Press (1954).
Prof. Dr. Gernot Grimmer 2000 Hamburg 39 Bebelallee 30 